RESEARCH ARTICLE

\title{
HOW GOVERNMENT PROVIDE LEGAL PROTECTION FOR TRADE SECRETS?
}

\author{
Idul Hanzah Alid ${ }^{\bowtie}$, Lailasari Ekaningsih ${ }^{2}$ \\ ${ }^{1}$ Postgraduate Program, Master of Laws, Universitas Negeri Semarang, Indonesia \\ ${ }^{2}$ Faculty of Law, Universitas Darul Ulum Islamic Centre Sudirman, Indonesia \\ $\triangle$ idoel@students.unnes.ac.id
}

\section{CITED AS}

Alid, I.H., \& Ekaningsih, L. (2020). How Government Provide Legal Protection for Trade Secrets? Journal of Law and Legal Reform, 1(2), 215-224. DOI: https://doi.org/ 10.15294/jllr.vli2.35420

\section{ABSTRACT}

Trade secret is a factor in the creation of innovation for a company to maintain its presence in the community. PT. CPM must identify information that is considered confidential trade before making attempts of legal protection of such information, because not all corporate information can be regarded as a trade secret. The identification is done by providing criteria for confidential information such as information that is not known by the public, has economic value, giving a loss if the information leaked and stolen. So PT. CPM has two attempts of legal protection of trade secrets. First, preventively is to have rules and regulations and written agreements between the parties relating to trade secret information PT. CPM. Second, repressive of protecting end to the measures for violations occurred. In case of violation, PT. CPM will solve the problem amicably. If it fails, then the next action to decide the employment of actors and reported to the authorities. Companies better make a written agreement between the parties in advance and posted to the Directorate General of Intellectual Property Rights in order to ensure the protection of the company's trade secrets.

Keywords: Identification, Protection Law, Trade Secrets, Plus Choice Makmur 


\section{TABLE OF CONTENTS}

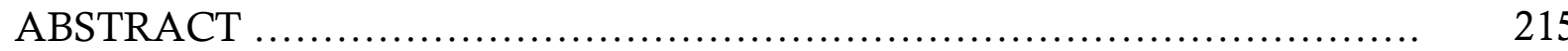

TABLE OF CONTENTS .................................................... 216

INTRODUCTION ........................................................ 216

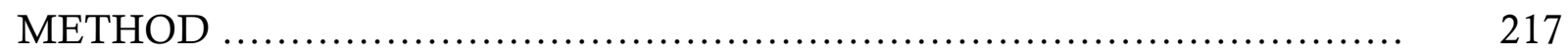

IDENTIFICATION OF INFORMATION CONSIDERED AS TRADE

SECRET FOR PT. CHOICE PLUS MAKMUR, SEMARANG REGENCY,

CENTRAL JAVA .................................................... 218

I. PRODUCTION SYSTEM IN PT. CHOICE PLUS MAKMUR ............. 218

II. IDENTIFICATION OF INFORMATION CONSIDERED AS TRADE

SECRET FOR PT. CHOICE PLUS MAKMUR ........................ 218

EFFORT IN LAW PROTECTION OF THE TRADE SECRET PT. CHOICE

PLUS MAKMUR ....................................................... 219

I. EFFORT IN LAW PROTECTION OF THE TRADE SECRET IN PT.

CHOICE PLUS MAKMUR .......................................... 219

II. THEORY OF LAW PROTECTION OF TRADE SECRET IN PT.

CHOICE PLUS MAKMUR ............................................ 221

CONCLUSION ........................................................ 222

REFERENCES ....................................................... 222

\section{INTRODUCTION}

Indonesian, one of the developing countries, have been applying a tight competition among the business, either micro, middle or high business. The competition occrus in several sectors such as trade and technology. Due to this competition, a company need improvement, new innovation and quality to maintain the business so that it will match the development in modern era. Semarang, both the city and regency, also have an increasing business competition.

Semarang regency has some potencies such as, human resources, natural resources and sufficient infrastructure that support the development of investment and business. The building of factories in the industry complex is expected to give multiplier effect and support the local economic income. One of those factories is PT. Choice Plus Makmur (CPM) which then becomes the object of this thesis. PT. CPM manufacturies various kinds of biscuit and coffe. Its sale target is Indonesian and China.PT. CPM always serves quilified product with continual inovation to maintain the existence and survival in the business. The information of trade secret of the company support the inovation. An a new company, it needs to protect its trade secrets from illegal action by irresponsible people.

Law No. 30/2000 about Trade Secret rules about the trade secrets. If there is another company wants to manufacture the same product, it must have the 
permission or license agreement. According to Law about Trade Secret No., 30/2000 section 5 (3), trade secret when it has license action with another side.

The main action to do is to identify whether an information is categorized as trade secret that must be kept and protected or not. Trade secrets is an information that is not known by public either in technology or business, and that has economic value. If an information does not have those criteria, it cannot be called as a trade secret information.

The definition of trade secret is information about formula pattern, compilation, program, technique or process that produce economic value in independent, real and potential way (Ramli, 2001). An Owner or Director of a company will not give the information of trade secret to his employee. He will be very careful and through in giving information about trade secret to his employee.

The existence of written agreement among all sides is necessary and will be the law power and protection to the company trade secret. It matches the section 1313, 1320 about the legal condition of an agreement and section 1234 about agreement not to give something, to do something or not to do something.

From the Law point of view, the law protection of trade secret is reasonable to do since the breaking of trade secret will lose the company in economic side. A trade secret becomes an essential factor in honest competition, and it will be the valuable comodity due its high economy value (Ramli, 2000). Based on the background, the writter states the problem as follows:

1. How can an information be identified as trade secret for PT. Choice Plus Makmur in Semarang Regency, Central Jawa?

2. How does PT. Choice Plus Makmur try to have Law Protection for its trade secret in Semarang Regency, Central Jawa?

\section{METHOD}

The method used in this research is normative juridical or literature law research. It means the research is done by observing the literature or merely secondary data (Soekanto \& ${ }^{2}$ Mamudji, 2013; Arifin, Waspiah, \& Latifiani, 2018). The the research of literature will be empowered by studying the real data. The data source is only secondary data which involves primary, secondary and tertiary law material.

The characteristic in this thesis is descriptive analysis. The object of the research is PT. Choice Plus Makmur, Semarang Regency, Central Jawa. The technique of collecting data in this research is documentation and interview. The data analysis is dones by in quantitaive way through recuction, presentation, conclusion and verification (Miles \& Huberman, 1992). 


\section{IDENTIFICATION OF INFORMATION CONSIDERED AS TRADE SECRET FOR PT. CHOICE PLUS MAKMUR, SEMARANG REGENCY, CENTRAL JAVA}

\section{PRODUCTION SYSTEM IN PT. CHOICE PLUS MAKMUR}

PT. Choice Plus Energi (CPE), estabilished in 2010 and centered in Jakarta, is the pioneer of the estabilishment of PT. CPM in Semarang Regency. Choice Plus Group is a company focused in the mining industry and power and natural resources industry (Choice Plus Energy, 2019).

PT. CPM as the combined company of PT. CPE is a private company which focus on the production of qualified biscuit, wafer. Potato crackers and instant coffee. For the sales channels, they have set up sales company in Hong Kong and Shenzhen in order to promote the products in different region, for the better service to their customers.

The production steps in PT. CPM are grinding, crhusing, weighing, mixing, cutting, ovening, cooling and packing/stacker. All products have fulfilled all export requirements set by Indonesian government and they match the agreement exported with the buyer in China. All items have paid the cost of health certificate. Besides, PT. CPM have made agreement with its buyer about the product package.

\section{IDENTIFICATION OF INFORMATION CONSIDERED AS TRADE SECRET FOR PT. CHOICE PLUS MAKMUR}

Identification is one way done to understand and know the characteristic of a person or thing. What is meant by identification in this research is to identifity an information that considered as secret by PT. CPM.

Secret information is an information unkwon by public because of its high economic value. It must be protected from illegal action so that it can support the business. According to Abdulkadir Muhammad, information is known as open and closed information (Muhammad, 2010). It can be said that secret information is categorized as closed informtaion which is unknown for public. It will be known only for the people who have authority to keep the secret information.

The secret information in this company that categorized as economic secret information, are production system, company prospect, company management, quilified product recipe, sale data and computer system. PT. CPM give limited and general information about product processing and its ingredient. The ingredient in making biscuit are butter, wheat and sugar. This information is an open information that can be knwon by anyone.

Since trade secret information is very crucial, Lab R\&D will save those written and softcopy data in a secret place. Only Lab R\&D and the director of PT. CPM will 
known about it. At stated in Law No. 8/1997 section 8 (1), each company must make note of company activity about the secret information data.

It also matches the Law of Trade section 6 and other bylaws about the way of saving, moving deleting and submitting files sure no longer appropiate with this era. There are factors that determine whether an information is categorized as secret or not: $a$ ) how many do people known about it, $b$ ) how many do employee and company people known about it, $c$ ) what does company do to keep the secret of its information, d) the value of the information for the company and its competition, e) how much effort and cost have been spent, $f$ ) the ease and difficulty to get or duplicate the information (Sukarmi, 2004).

The direct research from the Secretary od Director and Leader Lab R\&D, it can be stated that PT. CPM has secret information, including:

a. Important data known only by pointed people.

b. Data of secret information that is very important as the key in running all the production process in the company.

c. If those important and secret data are known by wrong person, it will cause a big company loss and it give bad impact to the company development in the future.

d. The information has selling value and economic value that must be protected for the company profile.

Several information thath kept secret and protected by PT. CPM are:

a. Computer system. It covers the technology use and management in every activities in PT. CPMfor example is purchasing.

b. The technique in operating modern technology machine during all the production stage.

c. The publication of brand and its logo.

d. The variety of taste. It is a very secret formula for the company that the Director gives limited information only to the Leader Lab R\&D, Buyer and Formula Consultant from Dutch.

e. Material Data Sheet or COA is data about the specification of the basic ingredient used in the production process.

\section{EFFORT IN LAW PROTECTION OF THE TRADE SECRET PT. CHOICE PLUS MAKMUR}

\section{EFFORT IN LAW PROTECTION OF THE TRADE SECRET IN PT. CHOICE PLUS MAKMUR}

Law protection is a place to take shelter or hide from any violation or infringement under the law or rules or judge"s sentences. Philipus M. Hadjon (1987) states that law protection of one's dignity and prestige, and acknowledgement of human rights based on the applied law. Philipus M. Hadjon states two form of law protection:

a. Preventive law protection is a protection given by government in order to prevent a violation. 
b. Repressive law protection is a final protection in the form of company responsibility, fine, prison or additional punishment given to the people who do violation.

The two kinds of law protection can be found in PT. CPM. First, as a preventive protection, PT. CPM has a company regulation that rules partnership, workers social assurance, company regulation, penalty and protection for company trade secret.

The agreement between the employer and his employee will create a responsibility to keep the company secret and will not break the applied law. The employer does it in order to protect the valuable information (Pratiwi, 2014; Susanti, 2019).

According to Santoso (2008), there are several actions to be done to protect the trade secret of the company:

a. A company must implement and maintain the policy to protect the company secret.

b. Give "top secret" label to the written material

c. Give supervision to the people who can access the company secret and make sure that only the permitted people who can open the secret materials

d. Save the secret material in the locked drawer by using a security system.

e. Computer data base must be secured using password.

f. If the company is developing certain product which needs a tester, make sure that the tester has signed a contract to keep the company secret

PT. CPM has done a work contract with its workers so that they will obey the company regulation and not to break it as stated in PT. CPM regulations section 28 section 1 and 2. In specific section, PT. CPM has a rule about the trade secret rules in section3l abot the Company secret. This section covers 4 points that number one states that :"Each companyy workers must keep the company secret about the technique, plan and pattern, production process, basic and additional materials, supplier, machinery, management system, new innovation, contracts with any references and buyers and anything about essential thing in the company.

This section of law protection gives two essential points, they are giving the clarity about the relationship between the employer ( as the information giver) and employee. This clarity gives the clear explanation about things to do and not to do by the employees. Second, by having rules and agreement about the trade secret will be the step to assure that the company about the law when there is a problem with the employee or other sides. PT CPM will also note the trade secret if it make a licenced parthnership with other sides.

Second, the repressive law protection. If a worker in PT CPM has broken the rules, PT CPM will give a small penalty, administrative penalty, and a big penalty. Those penalties are the form of repressive law protection. In section 34, it is stated that when a worker has broken the rules, s/he will get warning, scorsing, wages reduction and a retirement.

PT CPM has a good cooperation with cosultant from Dutch to improve its product. Unlike the subordinated cooperation with its workers, the cooperation with the consultant is a coordinative cooperation where both sides have the same 
position (Ramli. 2001). As a result, the agreement with the consultant is to have a cooperation in certain services.

According to Law of Trade Secret section 17, if someone is proven to break the agreement of law protection about trade secret, s/he will be threaten of 2 years in prison and fined 300 millions rupiah. As stated in section 35 letter g about the Company Rules, CPM has penalty for those who reveal the company secret and slander the name of company and its family.

CPM will discuss the problem with the worker personally at first. When it does not work, CPM will fire the worker and prosecute him and ask for the loss replacement.

\section{THEORY OF LAW PROTECTION OF TRADE SECRET IN PT. CHOICE PLUS MAKMUR}

This research uses three theories related to law protection in general, as highlighted by Waspiah (2009) (2017), Waspiah, Latifiani \& Setiawan (2015), they are:

a. Risk Theory

It explains that protection is given to the inventor because of his risky action in inventing his findings.

b. Reward Theory

This theory gives rewards for the inventor for his effort in inventing some works or creativity. This theory matches to the company regulation in article 26 paragraph 1 letter d about reward.

Those workers who do meritorious action and make the company proud of him or her will be given rewards.

c. Inventive Theory.

Based on reward theory, all the inventors will be very enthusiastic in inventing new innovation and $\mathrm{s}$ /he will be more creative. Moreover, company will give such kind of incentive to support those research activities.

According to Trade Secrets Law No 30 of 2000 as also emphasized and highlighted by Arifin (2019), the theoris about trade secret law are:

a. Theory of Property Rights

This theory states that an invention will be protected although it has not registered yet. The principle of Property rights is also mentioned in Civil Code in article 570. It is stated that an owner can dominate and use a property as long as it does not break the applied rules.

This research has found that CPM has the authority to dominate, utilize, and keep its invention, either technology or not, as a secret. It also can utilize and keep its secret formula of its invention as a secret.

b. Contract Theory

Contract Theory or Bond is a theory that explains the importance of an agreement between the company and its workers or other sides about company secret information. CPM hhas written agreement in the form of company regulation and 
closed written agreement that not all people can notice such as the written agreement between CPM and formula consultant drom Dutch.

c. Theory of Action breaking the law.

This theory is appropriate to be used as the basic protection of the trade secret from the sides who are ralate or ont relate to the agreement. This theory can be found in Civil Code article 365. For example, if CPM finds a worker or other pperson who steals and utilize a secret information without any legal permission, CPM will fire the worker directly and will imprison him/her and ask for compesation.

\section{CONCLUSION}

The paper concluded and highlighted that the riteria of information that considered to be trade secrets are, such as, (1) closed information that cannot be known by public but by the authorities only, (2) having economic value, (3) information that has specification and begins specifically, (4) a lot of effort and cost are needed to develop and protect the information, and (5) a lot of loss will be suffered if the secret is revealed. PT. CPM has two form of effort in protecting the right of its secret trade, such as, Preventive law protection is a kind of prevention done by government to avoid a infringement. PT. CPM has made a company regulation and letter of agreement with related sides, for example with formula expert from Dutch, and Repressive law protection is the final protection in the form of responsibility, fine, prison, and additional penalty given to the law breaker. CPM will give an administrative penalty as stated in in the company regulation article 34. CPM will discuss the problem as a family as the first step. But, when it fails, CPM will fire the worker who breaks the rule and will be imprisoned. According to Law No 302000 article 17 about trade secret, the one who break the law will get imprisoned for two years and fine 300 millions rupiah in maximum. Authors suggest that to avoid the infringement of trade secret, it is essential to make a written agreement among the ralated sides. It is suggested that government must socialize the importance of effort to protect the trade secret to the businessman.

\section{REFERENCES}

Arifin, R., Waspiah, W., \& Latifiani, D. (2018). Penulisan Karya Ilmiah untuk Mahasiswa Hukum. Semarang: BPFH UNNES.

Arifin, R. (2019). Indonesian Political Economic Policy and Economic Rights: An Analysis of Human Rights in the International Economic Law. Journal of Private and Commercial Law, 3(1), 38-49. https://doi.org/10.15294/jpcl.v3il.18178

Choice Plus Energy, online, http://choiceplusenergy.com/, accessed on 20 October 2019 Hadjon, P.M. (1987_. Perlindungan Hukum Bagi Rakyat Indonesia. Surabaya: Bina Ilmu. Indonesian Civil Code, Kitab Undang-Undang Hukum Perdata 
Law Number 30 of 2000 concerning Trade Secrets, Undang-Undang Nomor 30 Tahun 2000 Tentang Rahasia Dagang

Law Number 8 of 1997 concerning Company Documents, Undang-Undang Nomor 8 Tahun 1997 Tentang Dokumen Perusahaan

Miles, M.N., \&\&. Huberman, A.M. (1992). Analisis Data Kualitatif. translator Tjetjep Rohendi Rohidin. Jakarta: UI Press.

Muhammad, A. (2010). Hukum Perusahaan Indonesia. Bandung: PT Citra Aditya Bakti.

Pratiwi, A. N. M. A. D. (2014). Perlindungan Rahasia Dagang Setelah Berakhirnya Perjanjian Kerja. Thesis. Yogyakarta: Universitas Atma Jaya Yogyakarta.

Ramli, A.M. (2000). H.A.K.I: Teori Dasar Perlindungan Rahasia Dagang. Bandung: Mandar Maju.

Ramli, A.M. (2001). Perlindungan Rahasia Dagang dalam UU No. 30/2000 dan Perbandingannya Dengan Beberapa Negara. Bandung: Mandar Maju.

Soekanto, S., \& Mamudji, S. (2013). Penelitian Hukum Normatif Suatu Tinjauan Singkat. Jakarta: RajaGrafindo Persada.

Sukarni, S. (2004). Rahasia Dagang Sebagai Asset Bisnis Di Era Globalisasi. Jurnal Hukum, 14(1), 253-268.

Susanti, F. (2019). The Legal Efforts to Maintain the Authenticity of Trade Secrets through a License Agreement. Journal of Private and Commercial Law, 3(2), 71-75. DOI: https://doi.org/10.15294/jpcl.v3i2.19746

Waspiah, W. (2009). Perlindungan Hukum Melalui Pendaftaran Paten Sederhana Pada Inovasi Teknologi Tepat Guna Studi Kasus Di Kabupaten Tegal. Thesis. Semarang: Universitas Diponegoro.

Waspiah, W. (2017). Model Percepatan Komersialisasi Paten Sederhana pada Dunia Industri. Pandecta: Research Law Journal, 12(2), 183-202.

Waspiah, W., Latifiani, D., \& Setiawan, A. (2015). The Mechanism Model of The Simplepatent Registration (A Case Study in the Environmental Small Industries Semarang). South East Asia Journal of Contemporary Business, Economics and Law, 6(4), 20-27. 


\section{QUOTE}

The scope of our cybersecurity problem is enormous. Our government, our businesses, our trade secrets and our citizens' most sensitive information are all facing constant cyberattacks and reviews by the enemy

Donald Trump 